\title{
ДОСВІД ОРГАНІЗАЦІЇ ВНУТРІШНЬОГО АУДИТУ В НІМЕЧЧИНІ: ІСТОРИЧНИЙ ОГЛЯД ТА МЕТОДОЛОГІЯ
}

DOI: $10.32620 /$ cher.2020.2.09

Постановка проблеми. На сьогоднішній день досі існує дискусійне питання щодо введення у практику внутрішнього аудиту міжнародних стандартів. Як показав досвід зарубіжних країн, не всі країни підтримують застосування міжнародних стандартів, деякі, дотримуються думки, що краще використовувати національні стандарти. Однією з таких країн $є$ Німеччина з ії особливостями історичного та методологічного розвитку внутрішнього аудиту. Метою дослідження була розробка науково-практичних рекомендацій щодо вдосконалення процесу організації внутрішнього аудиту на прикладі досвіду Німеччини. Об'єкт дослідження. У статті увага приділяється дослідженню організації внутрішнього аудиту на підприємствах Німеччини. Методи, використані в дослідженні це системний підхід, порівняння, методи індукції та дедукції. Гіпотеза дослідження полягає в тому, що якість організації внутрішнього аудиту на підприємстві залежить від ефективності розроблених методологічних основ та нормативно-правового регулювання аудиту у певній країні. Виклад основного матеріалу. У нинішніх економічних умовах важливе місце належить дослідженням ролі внутрішнього аудиту та його місця серед інших видів контрольних процедур. Від надійності результатів внутрішнього аудиту залежить ефективність функціонування підприємства, яка в свою чергу впливає на ефективність всього суспільного виробництва. У міжнародній практиці внутрішній аудит давно отримав своє визнання. Німеччина $є$ однією з розвинутих європейських країн. Тому розглянуті питання організації в компаніях Німеччини системи внутрішнього контролю, управління ризиками, побудови служб внутрішнього аудиту, включаючи застосування стандартів внутрішнього аудиту, виходячи із законодавства ФРН і СС. Оригінальність та практична значимість дослідження полягає у розробці підходу до організації внутрішнього аудиту, що базується на урахуванні особливостей національного законодавства певної країни. Висновки. Результати досліджень підтверджують можливість застосування підходу до організації внутрішнього аудиту, що базується на урахуванні особливостей національного законодавства в Україні. Перспективою подальших досліджень стане подальший аналіз нормативно-правових положень організації внутрішнього аудиту Європейських країн на підприємствах різних організаційно-правових форм.

Ключові слова:

внутрішній аудит, міжнародні стандарти, методологія, контроллінг, підприємства.

\section{EXPERIENCE OF INTERNAL AUDIT ORGANIZATION IN GERMANY: HISTORICAL OVERVIEW AND METHODOLOGY}

Formulation of the problem. To date, there is still a debatable issue regarding the introduction of international standards in the practice of internal audit. As the experience of foreign countries has shown, not all countries support the application of international standards, some are of the opinion that it is better to use national standards. One of such countries is Germany with its peculiarities of historical and methodological development of internal audit. The purpose of the research was to develop scientific and practical recommendations for improving the process of organizing internal audit on the example of the experience of

${ }^{1}$ Столярчук Ганна Володимирівна, канд. екон. наук, доцент кафедри «Фінанси», Національний аерокосмічний університет ім. М.С. Жуковського «Харківський авіаційний інститут», м. Харків, Україна.

Stoliarchuk Hanna, Ph.D. in Economic, Associate Professor of Finances Department National Aerospace University «Kharkiv Aviation Institute», Kharkiv, Ukraine

ORCID ID: 0000-0002-5046-4298

e-mail: a.stolyarchuk@khai.edu

${ }^{2}$ Шевелін Марія Сергіївна, студент спеціальності 071 «Облік і оподаткування», Національний аерокосмічний університет ім. М. С. Жуковського «Харківський авіаційний інститут», м. Харків, Україна.

Shevelin Maria, student of 071 Accounting and Taxation Speciality, National Aerospace University «Kharkiv Aviation Institute», Kharkiv, Ukraine.

ORCID ID: 0000-0001-7317-8115

e-mail: mashashevelin3@gmail.com 
Germany. The object of research. The article focuses on the study of the organization of internal audit in German enterprises. The methods used in the research are a systematic approach, comparison, methods of induction and deduction. The hypothesis of the research is that the quality of the organization of internal audit at the enterprise depends on the effectiveness of the developed methodological framework and regulatory regulation of audit in a particular country. The statement of basic materials. In the current economic environment, an important place belongs to the study of the role of internal audit and its place among other types of control procedures. The reliability of the results of internal audit depends on the efficiency of the enterprise, which in turn affects the efficiency of all social production. In international practice, internal audit has long been recognized. Germany is one of the developed European countries. Therefore, the issues of organization of internal control systems in German companies, risk management, construction of internal audit services, including the application of internal audit standards, based on the legislation of Germany and the EU. Originality and practical significance of the research lies in the development of an approach to the organization of internal audit, based on the peculiarities of the national legislation of a particular country. Conclusions and perspectives of further research. The results of the research confirm the possibility of applying the approach to the organization of internal audit, which is based on the peculiarities of national legislation in Ukraine. The prospect of further research will be a further analysis of the legal provisions of the organization of internal audit of European countries at enterprises of various organizational and legal forms.

Key words:

internal audit, international standards, methodology, controlling, enterprises.

\section{ОПЫТ ОРГАНИЗАЦИИ ВНУТРЕННЕГО АУДИТА В ГЕРМАНИИ: ИСТОРИЧЕСКИЙ ОБЗОР И МЕТОДОЛОГИЯ}

Постановка проблемы. На сегодняшний день до сих пор существует дискуссионный вопрос о введении в практику внутреннего аудита международным стандартам. Как показал опыт зарубежных стран, не все страны поддерживают применение международных стандартов, некоторые придерживаются мнения, что лучше использовать национальные стандарты. Одной из таких стран является Германия с ее особенностями исторического и методологического развития внутреннего аудита. Целью исследования была разработка научно-практических рекомендаций по совершенствованию процесса организации внутреннего аудита на примере опыта Германии. Объект исследования. В статье внимание уделяется исследованию организации внутреннего аудита на предприятиях Германии. Методы, использованные в исследовании - это системный подход, сравнение, методы индукции и дедукции. Гипотеза исследования заключается в том, что качество организации внутреннего аудита на предприятии зависит от эффективности разработанных методологических основ и нормативно-правового регулирования аудита в определенной стране. Изложение основного материала. В нынешних экономических условиях важное место принадлежит исследованиям роли внутреннего аудита и его места среди других видов контрольных процедур. От надежности результатов внутреннего аудита зависит эффективность функционирования предприятия, которая в свою очередь влияет на эффективность всего общественного производства. В международной практике внутренний аудит давно получил свое признание. Германия является одной из развитых европейских стран. Поэтому рассмотрены вопросы организации в компаниях Германии системы внутреннего контроля, управления рисками, построения служб внутреннего аудита, включая применение стандартов внутреннего аудита, исходя из законодательства ФРГ и ЕС. Оригинальность и практическая значимость исследования заключается в разработке подхода к организации внутреннего аудита, основанного на учете особенностей национального законодательства определенной страны. Bыводы и перспективы дальнейших исследований. Результаты исследований подтверждают возможность применения подхода к организации внутреннего аудита, основанного на учете особенностей национального законодательства в Украине. Перспективой дальнейших исследований станет дальнейший анализ нормативноправовых положений организации внутреннего аудита Европейских стран на предприятиях различных организационно-правовых форм.

Ключевые слова:

внутренний аудит, международные стандарты, методология, контроллинг, предприятия.

Постановка проблеми. Дослідження історії та методології організації внутрішнього аудиту в провідних Свропейських країнах свідчать про те, що українські фахівці приділяють цій проблемі недостатньо уваги. А при розробці міжнародних стандартів внутрішнього аудиту, як показав досвід Німеччини, не враховуються особливості національного законодавства та економічні умови розвитку 
країни, що призводить до різних ускладнень у практичній діяльності аудиторів.

Аналіз останніх досліджень та публікацій. Існують результати досліджень концептуальних основ внутрішнього аудиту у Німеччині таких українських та російських вчених, як: Ф. Бутинець [1], О. Іванов [2], О. Петрик [3], В. Терехова [4] та інших. С наукові роботи, що належать німецьким вченим таким, як: Й. Вебер [5], Е. Майер [6], Р. Манн [7], Х. Куппер [8], В. Пеймоллер [9], Т. Райхман [10], Х. Фольмут [11], Д. Хан [12], П. Хорват [13], Д. Шнайдер [14] та іншим. Однак чіткого вирішення проблеми організації внутрішнього аудиту, орієнтованого на сучасні потреби національної економіки та права певної країни не має. Тому окреслена проблема $\epsilon$ актуальною i потребує дослідження.

Мета статті. Метою статті є запропонування підходу до організації внутрішнього аудиту суб'єктів господарювання, що базується на урахуванні особливостей національного законодавства та економічних умов розвитку певної країни, на прикладі Німеччини.

Виклад основного матеріалу дослідження. Розробка методології внутрішнього аудиту є неможливою без вивчення досвіду попередників. Окрім аналізу вітчизняних джерел, необхідно звертати увагу на роботи іноземних теоретиків та практиків внутрішнього аудиту. Подібний обмін досвідом сприяє пришвидшенню процесу вдосконалення галузі внутрішнього аудиту та формування багажу необхідних знань та навичок, відповідно до вимог динамічного ринкового середовища.

Вивчення вітчизняних та іноземних літературних джерел [1-14], у яких розглядалися проблеми внутрішнього контролю, показало, що дане питання по різному трактується представниками різних економічних шкіл. Так, організація внутріфірмового контролю за ефективністю та результативністю радянською школою називалася внутрішньогосподарським контролем, американською - внутрішнім аудитом, європейською - контролінгом. Отже, німецькі дослідники [5-14] ототожнюють внутрішньофірмовий контроль 3 контролінгом. Тому, звернімося до історії виникнення внутрішнього аудиту у Німеччинi.

Обліково-аудиторські

компанії

з'явилися в Німеччині у кінці дев'ятнадцятого століття. У 1907 році аудит почали вивчати у Лейпцигській колегії комерції [4]. Однак у комерційному законодавстві Німеччини термін «аудит» з'являється з 1931 року, коли аудит став обов'язковим для всіх великих компаній. 3 01.11.1961 року у ФРН діяв закон «Про аудит», який у 1975 році було доповнено, і в такому вигляді він діє у теперішній час.

В Німеччині зареєстровано більш ніж 1150 аудиторських фірм [9]. Однак, діяльність внутрішніх аудиторів Німеччини координує Інститут внутрішніх аудиторів. Починаючи 31995 p., Інститут внутрішніх аудиторів Німеччини активно бере участь у всесвітній координації та глобальних структурах професії завдяки членству в Міжнародному Інституті внутрішніх аудиторів. Члени Інституту внутрішніх аудиторів Німеччини беруть участь у численних комітетах Міжнародного Інституту внутрішніх аудиторів та заходах із представлення європейських та національних інтересів професії внутрішнього аудиту. Комітети Міжнародного Інституту внутрішніх аудиторів регулярно змінюються на міжнародному рівні.

Місією внутрішнього аудиту, як історично склалося, є збільшувати та зберігати вартість організації шляхом надання ризикорієнтованих та об'єктивних аудиторських послуг, консультацій та компетентних висновків.

Міжнародні основи професійної практики (IPPF) - це концептуальні основи, які організовують авторитетне керівництво, оприлюднене Інститутом внутрішніх аудиторів. Інститут внутрішнього аудиту по всьому світу надає авторитетне керівництво, як обов'язкове та і рекомендоване. Обов'язковими елементами міжнародних основ професійної практики внутрішнього аудиту є:

- основні принципи професійної практики внутрішнього аудиту;

- визначення внутрішнього аудиту;

- $\quad$ кодекс етики;

- міжнародні стандарти для професіоналів;

- положення 3 практики внутрішнього аудиту (стандарти).

Основні принципи професійної практики внутрішнього аудиту наступні [9]:

- $\quad$ демонструвати чесність;

- демонструвати компетентність та належну професійну ретельність; 
- бути об'єктивним і уникати неправомірного впливу;

- спрямовувати свою діяльність відповідно до стратегій, ризиків та цілей організації;

- $\quad$ мати належну підзвітність та адекватну забезпеченість ресурсами;

- демонструвати якісну роботу та постійне вдосконалення;

- ефективно надавати інформацію;

- надавати ризик-орієнтовані аудиторські послуги;

- демонструвати глибоке розуміння, проактивність та орієнтуватися на майбутнє;

- сприяти позитивним змінам в організації.

Інститут внутрішніх аудиторів Німеччини публікує результати роботи, а також подальший розвиток внутрішнього аудиту в теорії та практиці. Міжнародний Інститут внутрішніх аудиторів пропонує сертифікати в галузі внутрішнього аудиту та семінари для підготовки до іспиту. Іспити для отримання цих всесвітньо визнаних професійних кваліфікацій зараз проводяться у формі комп'ютерного тестування. Інститут Внутрішніх аудиторів Німеччини пропонує кваліфікацію внутрішнього аудитора (DIIR) з 2011 року. Кваліфікація внутрішнього аудитора являє собою професійну базову кваліфікацію без галузевого спрямування та документальних поглиблених базових знань досвідчених аудиторів. Ця подальша освіта спрямована на тих, хто хотів би продемонструвати знання важливих професійних базових знань про стандарти, методологію та процес внутрішнього аудиту. Крім того, внутрішній аудитор (DIIR) підтверджує знання у спеціальних галузях, що стосуються аудиту (таких як IT, шахрайство, аналітика) та важливих сферах бізнесу (фінансування, облік витрат, стратегічний контролінг та корпоративне управління). Навчання спрямоване насамперед на випускників професій, що потребують спеціальної підготовки (наприклад, банківських службовців або фахівців зі збуту на промислових підприємствах) та / або випускників університетів. Залежно від кваліфікації необхідний практичний досвід (мінімум 1 рік). Національні правові та нормативні питання враховуються як під час підготовки до іспиту на отримання сертифікату внутрішнього аудитора Німеччини, так і під час іспиту. Екзаменаційна та підготовча література здебільшого написана німецькою мовою.

Головне завдання внутрішнього аудиту в Німеччині, яке в минулому містилося лише 3 перевірки та оцінювання системи внутрішнього контролю, тепер є таким, що включає у себе одночасно складові трьох галузей, а саме управління ризиками, контролю та державного управління. Професор Волкер Х. Пеймоллер у своїй роботі $[9$, с.17] наголошує на тому, що внутрішній аудит є як реактивним, так і профілактичним, тобто таким, що діє на випередження: «Die interne Revision erbringt unabhängige und objektive Prüfungs- («assurance») und Beratungsdienstleistungen, welche darauf ausgerichtet sind, mehrwerte zu schaffen und die Geschäfstprozesse zu verbessern...».

Також, Пеймоллер у своїй роботі [9, c.17] акцентує увагу, що для працівників служб внутрішнього аудиту в Німеччині у край важливим $є$ те, щоб до них не висувалися ніякі правові вимоги, за виключенням Закону «Про контроль та прозорість у підприємницькій сфері» (Gesetz zur Kontrolle und Transparenz im Unternehmensbereich - KonTraG) [15] та Циркуляру «Про мінімальні вимоги до управління ризиками» (Rundschreiben 09/2017 Mindestanforderungen an das Risikomanagement - MaRisk) [16]. Отже, ми бачимо, що окрім міжнародних стандартів у сфері внутрішнього аудиту існують й нормативно-правові акти ФРН, що також регулюють дану сферу. Саме за виконання положень вказаних вище нормативно-правових актів ФРН хочуть нести відповідальність внутрішні аудитори. I в цьому існує проблема. 3 одного боку міжнародні стандарти, що регулюють сферу внутрішнього аудиту, а 3 іншого боку національні нормативно-правові акти.

Внутрішній аудит у Німеччині також регламентований Законом «Про акціонерні товариства» (Das deutsche Aktiengesetz AktG) [17] та Кодексом корпоративного управління (Der Deutsche Corporate Governance Kodex - DCGK) [18] як центральний елемент корпоративного управління, спрямований на формування системи внутрішнього контролю, завчасне виявлення небезпечних для компаній ризиків і управління ними.

У 2009 році в Німеччині був прийнятий Закон «Про модернізацію балансового права» (Das Gesetz zur Modernisierung des Bilanzrechts - BilMoG) [19], який теж регулює сферу внутрішнього аудиту. Поняття балансового права має європейське походження. Біля 
витоків балансознавства як науки стояли юристи, що визначають баланс як основний документ, який зміг би підтвердити здатність власників розрахуватися зі своїми кредиторами i, можливий для використання в якості доказової бази при вирішенні різних питань у господарських спорах. В кінці дев'ятнадцятого - на початку двадцятого століть великі юристи Свропи створили спеціалізовану галузь права - балансове право. Так, у 2009 році одним із напрямів реформи була дерегуляція та зниження витрат на користь малих та середніх компаній. 3 цією метою приватні підприємці звільнилися від зобов'язань із бухгалтерського обліку відповідно до комерційного законодавства, якщо вони лише мають малий бізнес. Крім того, у параграфі 267 Німецького комерційного кодексу (Handelsgesetzbuch - HGB), було підвищено на 20\% порогові значення величини активів та виручки, за якими підприємства мають розділяти на три групи: малі, середні та великі. Групування підприємств за розміром впливає на обсяг їх інформаційних зобов'язань та на обов'язковість проведення аудиту.

Крім того, економічна система всіх рівнів у Німеччині регулюється директивами та іншими нормативними документами Свросоюзу [2]. Отже, ми бачимо, що на розвиток методології внутрішнього аудиту в Німеччині мають вплив як міжнародні стандарти, так і нормативно-правові акти ФРН та Євросоюзу.

Після, дослідження німецьких літературних джерел [5-14] виявилося, що більшість німецьких економістів розуміють внутрішній аудит як контролінг. В той час українські економісти $[1,2]$ часто розуміють під внутрішнім аудитом внутрішньогосподарський контроль. Отже, вважаємо, що необхідно прояснити термінологічну плутанину, котра виникає внаслідок вживання слів «внутрішньогосподарський контроль» та «контролінг».

Практику контролінга було запозичено 3 Великої Британії як частину загальноприйнятої практики бізнесу відповідно до вимог правил «Company Acts» [4], що дійшли до нас із $1700-$-х років. Сам термін «controlling» зародився в Америці, в 70-ті роки поняття «контролінгу» потрапило в Західну Європу, а пізніше, на початку 90-х - у СНД [ 20]. Отже, «контролінг» походить від англійського «to control», «контролювати», «керувати», яке - у свою чергу, походить від французького відповідника, котре перекладається як «реєстр», «документальна перевірка». Незважаючи на це, в англомовних джерелах «контролінг» практично не застосовується: у Великобританії та США його замінили похідні терміни від «management» — «управляти» [20].

Дослідження літературних джерел [2, 3, 5-14] свідчать, що розуміння контролінгу, як підсистеми системи управління отримало найбільшого поширення у Німеччині. Подальший його розвиток носив двоякий характер установленні двох незалежних напрямів англо-саксонської (американської) та європейської (німецької) моделі. Між цими підходами існують відмінності не лише концептуального, але й термінологічного характеру - в англо,саксонській практиці застосовується поняття «управлінський облік» (management accounting), а «контролінг» практично не застосовується, хоча фахівців, що здійснюють ведення управлінського обліку, називають контролерами [3].

Розробка ідеї контролінгу грунтувалася на практиці його застосування в дочірніх фінансових установах американських корпорацій [3]. У перші роки до появи німці ставилися до нього критично. Значною мірою це було пов'язано із невірним тлумаченням. Так, контролінг ототожнювали 3 контролем, а повноваження контролера перебільшувалися та розцінювалися як безпосередня загроза застосування штрафних санкцій для управлінців [3]. Згодом, апробувавши на практиці ідеї контролінгу, його стали сприймати позитивно, і чільним стало прагнення перенесення його ідей у практику фінансовогосподарської діяльності підприємств Німеччини [3].

На сьогоднішній час у німецьких економістів не має одностайного підходу до розуміння процесу контролінгу і питання щодо його організації досі є дискутивним.

Так, Хорват П. [13], розглядаючи контролінг у розрізі цілей фінансової установи, вважає, що система контролю повинна забезпечувати керівництво інформацією та підштовхувати його до координування, реагування та адаптації до мінливих внутрішніх і зовнішніх умов для ефективної реалізації стратегічних цілей.

Райхман Т. [10], як і Ховат П., приділяе особливу увагу орієнтації контролінгу на результат (з урахуванням забезпечення ліквідності) і бачить основне завдання контролінгу в зборі та обробці інформації в процесі роз- 
робки, координації та контролю виконання планів фінансової установи.

Інше бачення на розуміння контролінгу має Куппер Х.Ю [8]. Він вбачає центральну проблему контролінгу у координації системи управління фінансової установи.

Враховуючи думку Куппера Х.Ю. та Хорвата П., Вебер Й. [5] вважає, що контролінг — це в першу чергу, інструмент координації. В його інтерпретації контролінг $є$ елементом управління соціальною системою, виконуючи свою головну функцію підтримки управлінського персоналу в процесі вирішення покладеного на нього завдання координації системи управління із акцентом, насамперед, на планування, контроль та інформування.

3 точки зору Шнайдера Д. [14], завдання контролінгу, яке полягає у координації в сенсі загальної координації управління (за Куппером й Вебером), має бути обмеженим. 3 одного боку, функція контролінгу повинна зводитися до розробки й координації окремих планів фінансової установи та зведення їх у єдиний план, а $з$ іншого боку - до внутрішнього виробничого обліку, який є більш приорітетним для контролю, ніж процес досягнення планових показників, оскільки формує інформаційну базу для подальшого планування. Рекомендоване Шнайдером Д. обмеження функцій контролінгу властиве німецькій концепції контролінгу, у якій на перше місце ставиться комплекс завдань планування 3 інтегрованою системою плановоконтрольних розрахунків на базі інформації внутрішнього виробничого обліку [14].

Після теоретичного аналізу сутності контролінгу, проведемо дослідження як у практичній діяльності підприємств реалізуються його функції. Розглянемо у таблиці 1 , статистичну інформацію з обсягу додаткових послуг, що надаються внутрішніми аудиторами підприємств у Німеччині [21].

Середня питома вага підприємств, на яких надавалися додаткові види послуг внутрішніми аудиторами за період з 2011 по 2017 роки, подана в таблиці 1.

Т а б ли ц я 1

Питома вага підприємств, на яких внутрішніми аудиторами надавалися додаткові послуги

\begin{tabular}{|l|c|}
\hline \multicolumn{1}{|c|}{ Додаткові види послуг з внутрішнього аудиту } & Питома вага, \% \\
\hline Не має додаткових послуг & 64,8 \\
\hline Відповідність стандартам чи нормам (Compliance) & 11,9 \\
\hline Захист інформації (Datenschutz) & 10,1 \\
\hline Управління якістю (Quality management) & 2,3 \\
\hline Юридичні послуги (Recht) & 0,8 \\
\hline Управління ризиками (Risikomanagement/Risikocontrolling) & 10,9 \\
\hline Інші & 13,4 \\
\hline
\end{tabular}

Джерело: складено авторами на підставі [21]

Результати дослідження показали, що понад 95\% підприємств-учасників мають власний відділ аудиту. У п'ятьох організаціях аудитор виконує функцію аудиту повністю, а в п'ятнадцяти інших організаціях аудиторську функцію виконують інші внутрішні підрозділи (наприклад, контролю, обліку, якості, управління ризиками).

У таблиці 1 показано питому вагу інших послуг внутрішнього аудиту, які виконуються на додаток до аудиту. Частка підрозділів внутрішнього аудиту чи аудиторів, які виконують лише послуги аудиту, знову незначно зросла (2011 р.: 60\%; 2014 р. 63\%; 2017 p. 65\%). Однак послуги управління ризиками (11\%), захисту даних $(10 \%)$ та відповідності (12\%) виконують відносно невелика кількість аудиторських підрозділів.
Знову ж таки, слід поставити під сумнів, наскільки можливі додаткові послуги внутрішнього аудиту тому, що їх виконання призводить до погіршення незалежності та об'єктивності аудиторів. У табл. 1 видно, що понад $64 \%$ опитаних підприємств не мають аудиторів або аудиторських підрозділів, що надають інші послуги. Однак якщо додаткові послуги з внутрішнього аудиту надаються, то на підприємствах слід забезпечити вживання відповідних заходів для обмеження порушень незалежності та об'єктивності працівників відділів внутрішнього аудиту.

Спектр можливих додаткових послуг 3 внутрішнього аудиту поза основними категоріями дуже різноманітний. Наприклад, у розділі «Інше» учасники опитування часто вказують такі послуги: 
- запобігання корупції;

- налаштування структурованих кабельних систем ICS та тести ICS;

- навчання та поради раді директорів;

- безпека, захист працівників, захист рослин;

- розробка політики управління підприємством;

- безпека IT та управління авторизацією та діджиталізація;

- підтримка проекту.

Отже, $з$ практичного досвіду підприємств Німеччини, ми побачили, що внутрішній аудит охоплює більш широкий спектр послуг, ніж внутрішньогосподарський контроль. Таким чином, поняття контролінгу, який включає у себе всі розглянуті вище додаткові послуги, значно ширше, ніж поняття внутрішньогосподарського контролю.

Висновки та перспективи подальших досліджень. Результати проведеного дослідження дозволили виявити, , що у практиці підприємств Німеччини немає єдиного бачення структури та завдань системи контролінгу. Розуміння необхідності проведення внутрішнього аудиту доводить усвідомлення керівництвом підприємств переваг, які досягаються завдяки впровадженню систем контролінгу, починаючи із 1974 р. Понад 90\% великих європейських підприємств організували власний підрозділ контролінгу. Окрім цього, їх досвід наслідують підприємства малого та середнього бізнесу, які також намагаються підвищити власну ефективність шляхом виявлення помилок та роботи над ними. Вважаємо, що така зарубіжна практика була б корисною і для Українських підприємств. Так, напрямком подальших досліджень доцільно обрати вивчення практики застосування інструментів і методів внутрішнього аудиту на підприємствах різних розмірів та організаційно-правових форм.

\section{Література}

1. Бутинець Ф. Ф., Малюга Н. М., Петренко Н. І. Аудит: стан та тендениї розвитку в Україні та світі: монографія. Житомир: ЖДТУ, 2004. 564 с.

2. Иванов Ю. Б. Организация внутреннего аудита в компаниях Германии. ЭТАП. 2013. № 5. С. 129-14.
3. Петрик О.А. Аудит: методологія $i$ організаиія: монографія. Київ: КНЕУ, 2003. $260 \mathrm{c}$.

4. Терехова А. Зарубежный опыт организации аудита: краткий исторический обзор и методология. Международный бухгалтерский учет. 2002. № 1. С. 22-27.

5. Weber J.: Einführung in das Controlling, Stuttgart. Sammlung: Poeschel, Band. 1996. $133 \mathrm{p}$.

6. Mayer E., Weber J. (Hrsg.): Handbuch Controlling, Stuttgart, 1990. 1047 s.

7. Mann R., Mayer E. Controlling für Einsteiger (Rezeptbuch), Freiburg, 1995. 182 s.

8. Küpper H. U. (Hrsg.): Controlling, Stuttgart, 1997. $321 \mathrm{~s}$.

9. Peemöller V., Kregel J. Grundlagen der Internen Revision: Standards, Aufbau und Führung: Handbücher der Revisionspraxis, Erich Schmidt Verlag GmbH \& Co KG, 2010, $428 \mathrm{~s}$.

10. Reichmann T. Kennzahlengestützte Controlling-Konzeption, in: Schrm, E. / Pitsch, G. (Hrsg., 2004), S. 83-101.

11. Vollmuth Hilmar Führungsinstrument Controlling: Planung, Kontrolle und Steurung, 2001, Planegg, S.11.

12. Hahn Dietger Controlling in Deutschland - State of the Art in: Gleich, R./ Seidenschwarz, W.(Hrsg., 1997), S.13-46.

13. Horváth, Péter Controlling: Zeitschrift für erfolgsorientierte Unternehmenssteuerung. München : Beck, ZDB-ID 649545-X. Vol. 31.2019, Spezialausgabe, p. 4-9.

14. Schneider Dieter Controlling als postmodernes Potpourri, in: Controlling, 17. Jg., 2019, S. 65-69.

15. Gesetz zur Kontrolle und Transparenz im Unternehmensbereich - KonTraG. URL: https://www.bgbl.de/xaver/bgbl/start.xav.

16. Rundschreiben 09/2017 Mindestanforderungen an das Risikomanagement MaRisk URL: https://www.bafin.de.

17. Das deutsche Aktiengesetz - AktG. URL: https://www.gesetze-im-internet.de/aktg/.

18. Der Deutsche Corporate Governance Kodex - DCGK. URL: https://www.dcgk.de/en/code//foreword.html.

19. Das Gesetz zur Modernisierung des Bilanzrechts - BilMoG. URL: https://www.bundesgerichtshof.de/DE/Bibliothe k/GesMat/WP16/B/bilmog.html.

20. Controlling. https://uk.wikipedia.org/wiki/Controlling. 
21. Enquete 2017: Die Interne Revision in Deutschland, Österreich und der Schweiz. URL : https://www.diir.de/fileadmin_2017.

\section{Reference}

1. Butints, F., Efimova, F. F., Malyuga, N. M. and Petrenko, N.I. (2004). Audit: state and development trends in Ukraine and the world: monograph. Zhytomyr: ZhDTU, 564.

2. Ivanov, Yu. (2013). Organization of internal audit in German companies. ETAP, 5, 129-14.

3. Petrik, O. (2003). Audit: methodology and organization: monograph. Kyiv: KNEU, 260.

4. Terekhova, A. (2002). Foreign experience in organizing an audit: a brief historical review and methodology. International Accounting, 1, 22-27.

5. Weber, J. (1995). Introduction to Controlling, Stuttgart, Poeschel Collection, volume 133.

6. Mayer, E., Weber, J. (1990). Handbuch Controlling, Stuttgart, 1047.

7. Mann R., Mayer, E. (1995). Controlling for beginners (recipe book). Freiburg. 1995. 182.

8. Küpper, H. (1997): Controlling, Stuttgart, 321.

9. Peemöller, V., Kregel, J. (2010). Fundamentals of Internal Audit: Standards, Structure and Management. Manuals of Revision Practice, Erich Schmidt Verlag GmbH \& Co KG, 428.

10. Reichmann, T. (2004). Key figurebased controlling concept, 83-101.

Стаття надійшла

до редакції : 25.05.2020 p.
11. Vollmuth Hilmar (2001). Management tool controlling: planning, control and steering, Planegg, 11.

12. Hahn, Dietger (1997). Controlling in Germany - State of the Art in: Gleich, 13-46.

13. Horváth, Péter (2019). Controlling: Magazine for success-oriented corporate management. Munich: Beck, ZDB-ID 649545-X. Vol. 31.2019, special edition, 4-9.

14. Schneider, Dieter (2019). Controlling as postmodern potpourri, in: Controlling, 17.Jg., 65-69.

15. Law on Control and Transparency in Business. Retriveid from: https://www.bgbl.de/.

16. Circular 09/2017 Minimum requirements for risk management - MaRisk. Retriveid from: https://www.bafin.de/SharedDocs/ Veroeffentlichungen/DE/Rundschreiben/ 2017/rs_1709_marisk_ba.html.

17. The German Stock Corporation Act. Retriveid from: https://www.gesetze-iminternet.de/aktg/.

18. The German Corporate Governance Code. Retriveid from: https://www.dcgk.de/en/code//foreword.html.

19. The law for the modernization of balance law. Retriveid from: https://www.bundesgerichtshof.de/DE/Bibliothe k/GesMat/WP16/B/bilmog.html.

20. Controlling Retriveid from: https://uk.wikipedia.org/wiki/Controlling.

21. Enquete 2017: The internal audit in Germany, Austria and Switzerland. Retriveid from: https://www.diir.de/fileadmin/EnqueteBroschuere_2017
Стаття прийнята
до друку: 26.06.2020 p.

\section{Бібліографічний опис для цитування :}

Столярчук Г. В. Досвід організації внутрішнього аудиту в Німеччині: історичний огляд та методологія / Г. В. Столярчук, М. С. Шевелін // Часопис економічних реформ. - 2020. - № 2 (38). C. $71-78$. 